\title{
MATERNAL EDUCATIONAL PRACTICES DURING THE FIRST YEAR OF LIFE
}

\author{
Elisa Rachel Pisani Altafim¹, Olga Maria Piazentin Rolim Rodrigues²
}

\begin{abstract}
:
Introduction: The strategies used by parents in education and childcare play a major role in the child's development and health. Objective: To describe and analyse the maternal educational practices during the first year of life. Methods: A total of 250 mothers of infants between 1-12 months participated in the study. The data was collected using the Parental Styles Inventory for Mothers of Babies (IEPMB). Results: Mothers used the positive parenting practice: Monitoring Positive. However negative practices were also present in the repertoire of the participants, especially Relaxed Discipline. Conclusion: The negative practices were not common in the behavioural repertoire of the mothers, so this phase is an appropriate stage to promote preventative interventions aimed at improving the mother-infant relationship, and therefore impacting health prevention, health promotion and child development.
\end{abstract}

Keywords: educational practices, maternal behaviour, mother-child relationship, the first year of life.

\section{INTRODUCTION}

The quality of parenting strategies used to guide children's behaviour is a changeable risk factor that can contribute to developing behavioural and emotional problems in children ${ }^{1}$. These strategies are called parenting educational practices ${ }^{2}$. Parenting educational practices can act as protection mechanisms, or as risk factors for child development ${ }^{3}$. Children's exposure to negative and inadequate parenting practices or no emotional involvement with parents, are risk factors for child development, increasing their vulnerability to external events threatening their family environment ${ }^{4}$. The use of negative parenting practices was positively correlated with depression, stress and low repertoire of children's social skills ${ }^{5}$.

Parenting educational practices can be classified as positive and negative ${ }^{6}$. Positive practices are related to the development of prosocial behaviour, and negative ones related to antisocial behaviour ${ }^{6}$. Two practices are considered to be positive: Positive Monitoring and Moral Behaviour. Five practices are considered to be negative: Negligence, Physical Abuse, Relaxed Discipline, Inconsistent Punishment and Negative Monitoring. Infants' mothers use these practices with the exception of moral practices and negative monitoring behaviour ${ }^{7}$.
Positive Monitoring practice involves attention to child's location, activities and ways to adapt in different contexts ${ }^{8}$. Expressions of affection, especially those related to child's needs, are also components of Positive Monitoring ${ }^{6}$. Negligence involves the lack of attention and affection ${ }^{6}$. Negligent parents act as spectators rather than participants of child care and education ${ }^{9}$. Relaxed Discipline practice implies non-compliance of preestablished rules ${ }^{6}$. Physical Abuse includes the use of threats and physical punishment. Inconsistent Punishment depends on adult's moods to punish or strengthen children's behaviour ${ }^{6}$.

Studies aiming to identify parenting practices, in the first year of life, can support early interventions aiming to promote child development and family relationships. In early childhood it is possible to identify parenting educational practices that impact children's behaviour. Studies have been conducted with infants' mothers to identify the relationship between parenting practices and variables such as child and maternal age ${ }^{7}$, as well as an intervention programme conducted with adolescent mothers ${ }^{10}$.

A Brazilian literature review about parenting practices analysed 64 national studies ${ }^{11}$. The results highlighted a gap regarding research focused on parenting practices during the child's first year of life and measuring instruments that can be used

\footnotetext{
1 Post graduation programme in Mental Health at Medicine Faculty of Ribeirão Preto - USP . Scholarship from Support to Research Foundation of Sao Paulo State (FAPESP).

2 Psychology Department Universidade Estadual Paulista Júlio de Mesquita Filho, campus Bauru.

Corresponding author: Elisa Rachel Pisani Altafim. E-mail: altafim.elisa@gmail.com/elisa.altafim@usp.br
}

Suggested citation: Altafim ER, Rodrigues OMPR. Maternal Educational Practices during the first year of life. Journal of Human Growth and Development. 25(2): 257-262. Doi: http://dx.doi.org/10.7322/jhgd.105999

Manuscript submitted Oct 22 2014, accepted for publication Dec 192014. 
for this investigation ${ }^{11}$. Among studies that focused on early childhood, in general they investigated parenting practices with children close to three years old and not in the first two years of life ${ }^{11}$.

Assessing the early parent-child relationship is a way to act in prevention and promotion of family health and child development, since the patterns of relationship are still being established ${ }^{11}$. Parenting programmes that help and support parents in the task of educating their children can seek to minimise the level of parental stress, favouring the development of coping strategies in adverse situations ${ }^{12 .}$

Before offering information and advice to parents, it is necessary to have an analysis of the educational practices used by them. There are still gaps in the national literature that have investigated the parenting practices during the first year of life. Therefore, the aim of this study was to describe and analyse the parenting educational practices of mothers in the first year of their child's life.

\section{METHODS}

This is a cross-sectional and descriptive study. The participants included 250 mothers of infants, from one to 12 months of age, attending the extension project 'Monitoring babies' development: evaluation and guidance for parents' conducted in the Applied Psychology Center (CPA), UNESP, Bauru - São Paulo, Brazil. With respect to maternal age, 114 participants ranged between 14-19 years old (mean age $=17.09, \mathrm{SD}=1.42)$ and 136 ranged between 20-46 years old (mean age $=27.85$; SD $=6.11$ ). Regarding the children's characteristics, 124 were female and 126 male, 159 were from one to six months old (mean age $=3.28, \mathrm{SD}=1.51$ ) and 91 from seven to 12 months old (mean age = 9.35, SD = 1.69).

For identification of parenting practices, the instrument Parenting Styles Inventory for Babies'
Mothers (IEPMB) ${ }^{7}$ was used, adapted from the Parental Styles Inventory ${ }^{6}$. The adaptation of the instrument was necessary because in the national literature, an assessment of parenting practices in the first year of life was not found. This instrument consists of 25 items, grouped into five sets of parenting practices: Positive Monitoring, Negligence, Physical Abuse, Relaxed Discipline and Inconsistent Punishment. Using a Likert scale of three points, the answer "always" was worth 2 points, "sometimes" worth 1 point, and "never" worth 0 (zero) points. Therefore, each parenting educational practice can have a maximum score of 10 points. A higher score on the negative parenting practices meant worse practices. For Positive Monitoring a high score meant better practices. The IEPMB has been used in several studies and has been shown to be an efficient and easy tool for early identification of parenting practices ${ }^{7,10,13}$.

For data collection, the IEPMB was administered individually. To ensure understanding of the inventory, the researcher read the instructions with the participant. For data analysis, parenting practices and investigated questions were described. Comparative analyses of the parenting practices were conducted using a paired t-test ( $p$ $<0.05$ ). The project was approved by the Ethics Committee of the Faculty of Sciences, UNESP, Bauru - SP (Process number 451/46/01/09).

\section{RESULTS}

The analysis of each set of parenting practices of IEPMB showed that Positive Monitoring was the practice most frequently used by participants (Table 1 ). The negative practice that was reported most often by mothers was Relaxed Discipline followed by Inconsistent Punishment and Negligence practices. The practice less frequently used was Physical Abuse. The sum of the four negative practices was lower than Positive Monitoring (Table 1).

Table 1: Means, standard deviations, minimum and maximum values of each parenting practice

\begin{tabular}{|c|c|c|c|c|}
\hline Practices & Mean & Standard Deviation & Minimum & Maximum \\
\hline Positive Monitoring & 8.54 & 1.54 & 3 & 10 \\
\hline Negligence & 1.37 & 1.35 & 0 & 7 \\
\hline Physical Abuse & 0.38 & 0.77 & 0 & 4 \\
\hline Relaxed Discipline & 4.8 & 2.4 & 0 & 10 \\
\hline Inconsistent Punishment & 1.7 & 1.59 & 0 & 6 \\
\hline Negative Practices Sum & 7.66 & 4.2 & 0 & 21 \\
\hline
\end{tabular}

Comparing the responses of each parenting practice using a paired test, a significant intragroup differences was found $(p<0.01)$ for all the practices. The participants responded differently for each parenting practice. The participants used Positive Monitoring more than Relaxed Discipline, Inconsistent Punishment, Negligence, and Physical Abuse. Among the negative practices, Relaxed Discipline was most often used.
A frequency analysis of the different questions comparing each parenting practices was performed (Table 2). In Positive Monitoring, the participants had a similar answer for questions 5, 11 and 18 . Most of them reported using these practices often. Questions 16 and 23 appeared less frequently on participants' report. Questions 1 and 7 from Inconsistent Punishment practice were the most frequent, followed by question 12 . Questions 19 and 
17 were reported by a smaller number of participants. The Negligence practice was not used very often by mothers. Of the five questions, 2, 13 and 20 were those which appeared in the report by a larger number of participants. Questions 8 and 24 were the least reported. The practice Relaxed Discipline was often reported by mothers. Questions
$6,9,14$ and 21 were reported by a significant number of participants. Question 3 appeared in fewer participants. The Physical Abuse practice appeared in the account of a few participants. Questions 4 and 10 were the most frequently reported, and questions 15, 22 and 25 appeared in the report of a few participants.

Table 2: Number of participants who reported using each parenting practice, percentage and means for each question

\begin{tabular}{|c|c|c|c|}
\hline Parenting Practices & $\mathbf{N}=\mathbf{2 5 0}$ & $\%$ & Mean \\
\hline \multicolumn{4}{|l|}{ Positive Monitoring } \\
\hline 5- I demand to know how my child was in my absence. & 237 & $94.8 \%$ & 1.83 \\
\hline 11- When my child is crying I try to figure out what bothers him or her. & 241 & $96.4 \%$ & 1.89 \\
\hline 16- Even when I'm busy or traveling, I phone to find out how my child is. & 209 & $83.6 \%$ & 1.60 \\
\hline $\begin{array}{l}\text { 18- After staying away from my child I ask the caregiver how he or she } \\
\text { behaved (example: if he or she cried; if he or she was fine). }\end{array}$ & 236 & $94.4 \%$ & 1.85 \\
\hline 23- I establish a routine with my child and try to follow it. & 218 & $87.2 \%$ & 1.44 \\
\hline \multicolumn{4}{|l|}{ Inconsistent Punishment } \\
\hline $\begin{array}{l}\text { 1- When my child does something that displeases me, the way I answer } \\
\text { it depends on my mood. }\end{array}$ & 122 & $48.8 \%$ & 0.54 \\
\hline $\begin{array}{l}\text { 7- When I'm happy I do not care about my son's or daughter's behaviours } \\
\text { that displease me. }\end{array}$ & 104 & $41.6 \%$ & 0.6 \\
\hline $\begin{array}{l}\text { 12- I mistreat my son or daughter when I'm nervous and when the anger } \\
\text { passes I regret it. }\end{array}$ & 53 & $21.2 \%$ & 0.25 \\
\hline 17- When I'm nervous, I end up taking it out on my son or daughter. & 39 & $15.6 \%$ & 0.16 \\
\hline 19- I'm bad-tempered with my child. & 36 & $14.4 \%$ & 0.15 \\
\hline \multicolumn{4}{|l|}{ Negligence } \\
\hline 2- My work disrupts the attention I give to my child. & 70 & $28 \%$ & 0.34 \\
\hline $\begin{array}{l}\text { 8- When my child cries, he or she seeks another person because I am } \\
\text { always busy. }\end{array}$ & 24 & $9.6 \%$ & 0.11 \\
\hline 13- My child stays with others caregivers most of the time. & 73 & $29.2 \%$ & 0.34 \\
\hline 20- I do not know what my child likes. & 92 & $36.8 \%$ & 0.5 \\
\hline 24- I leave my child's problems for others to solve. & 10 & $4 \%$ & 0.05 \\
\hline \multicolumn{4}{|l|}{ Relaxed Discipline } \\
\hline $\begin{array}{l}\text { 3- I threaten that I will beat or get too mad with my child, but then I do } \\
\text { nothing. }\end{array}$ & 105 & $42 \%$ & 0.52 \\
\hline 6- I establish a routine but can never follow it. & 159 & $63.6 \%$ & 0.82 \\
\hline $\begin{array}{l}\text { 9- If my child cries, I say that I will not catch him or her, but if he or she } \\
\text { insists on crying, I catch him or her. }\end{array}$ & 172 & $68.8 \%$ & 1.05 \\
\hline 14- I don't make time for my child, things happen naturally. & 148 & $59.2 \%$ & 0.86 \\
\hline $\begin{array}{l}\text { 21- I notice that I will not put my child in my arms when he or she throws } \\
\text { a tantrum, but then I get pity and end up doing it. }\end{array}$ & 162 & $64.8 \%$ & 0.94 \\
\hline \multicolumn{4}{|l|}{ Physical Abuse } \\
\hline 4- I hit my child with my hand or with some objects & 26 & $10.4 \%$ & 0.15 \\
\hline 10- My child is very afraid of me. & 33 & $13.2 \%$ & 0.16 \\
\hline 15- My child is physically hurt when I hit him or her. & 2 & $0.8 \%$ & 0.01 \\
\hline 22- I am aggressive with my child. & 8 & $3.2 \%$ & 0.04 \\
\hline 25- I am violent with my child. & 4 & $1.6 \%$ & 0.02 \\
\hline
\end{tabular}

$\mathrm{N}=$ number of participants who reported using the practice always or sometimes.

$M=$ mean response of participants.

\section{DISCUSSION}

The practice of Positive Monitoring was frequently used by infants' mothers. This was already pointed out by other studies ${ }^{7,13}$. Positive Monitoring in the first year of a child's life involves attention to the location of the child, even when the mother is absent as she cares to know how her child behaved; and concern for their activities, which would be related to establishing a routine and recognising behaviours of infants, for example, crying. Positive Monitoring allows the mother to show herself as present and adequately meet the needs of her child.

When the mother asks how her child was in her absence, she is obtaining data to understand her child's behaviour. Therefore, if some difficulty appears, this information may be important for a more accurate description, proper interpretation and a contingent response to the child's behaviour. This behaviour informs the mother about the quality of interactions between her child and caregivers and establishes a trust relationship. All these aspects are essential for establishing a healthy emotional 
bond that provides safety for the child and subsequent independence. A study found that in situations where the mother has to leave her child with another caregiver most of them (66\%) reported feelings of worry, apprehension, sadness, fear, anxiety, shame and missing the child ${ }^{14}$. However, mothers also reported a feeling of safety when they had reliable support figures to take care of the child $^{14}$. Positive Monitoring can help mothers establish a trust relationship with other caregivers.

Most participants reported that they tried to find out what was bothering the child when he or she cries. These mothers are acting responsively, since through crying recognition they try to distinguish the real child's needs. Therefore, they can offer a contingent and appropriate response to the child's signals. Crying is the basic means of infant's communication.

The use of negative parenting practices were also mentioned by participants, although less frequently than positive parenting practices. Among negative practices, Relaxed Discipline was most often reported. Four out of five questions investigated appeared in the report of more than half the participants. These behaviours were part of most participants' repertoire. Even in the case of young children, this practice was an important strategy used by mothers for child's behaviour regulation.

Relaxed Discipline appeared mainly in questions 9 and 21, related to the conduct of saying that she will not catch the infant when he or she cries or has tantrums and ends up doing it. These behaviours result in intermittent reinforcement, sometimes with the mother catching the infant and sometimes not, and take more or less time. This condition reinforces the child's tantrums and crying to get attention that he or she never knows if it will come. Children's tantrums may be functionally related to the inconsistency of parents/caregivers, because often, when requests of children are denied, and they cry and scream, caregivers end up giving what at another time was denied. This parenting practice shows the child inconsistent parent behaviour characterised as an intermittent reinforcer, which is quite powerful in maintaining behaviours ${ }^{15}$.

Two other questions that appeared in the report of a significant number of participants were 14 and 6 . These questions were related to routine. In Positive Monitoring a significant number of participants reported that they established a routine and tried to follow it. However, a significant number of participants also reported establishing a routine and could not follow it, or did not make time for children, letting things happen naturally. These data showed that mothers were a little confused about the real importance of routine, or were having difficult following it.

This result may be related to other variables such as maternal education. A study conducted with mothers who had graduated high school and had children from two to seven years old, found that, although some mothers did not determine a daily routine for the child $(4.5 \%)$, or left this assignment to the child $(20.5 \%)$, most of the time mothers established a routine alone $(17.5 \%)$ or together with child $(57.5 \%)^{16}$.

Routine establishment allows both infant and mother to make predictions about the behaviour and the environment, which can bring many benefits, such as sleep regulation and infant feeding. Predictability allows the organisation of mother's and child's behavioural repertoire. Mothers can observe and describe at what time the child gets sleepy, is tired, hungry or wants to play. The routine allows for a more accurate interpretation of infant signals, and therefore a contingent response to the child's behaviour. Also, when there is a routine, any unforeseen circumstance can be solved more readily without harming the child's attention and care ${ }^{17}$. The routine brings security for parents and children and allows greater family organisation.

Results showed that mothers established rules, but seemed to not pay attention to the importance of following them. If mothers often establish rules but do not enforce, the child will develop basically three types of attitudes: the first is learning that rules are not to be met; the second is the possibility of disregarding authority; and the third is learning to emotionally manipulate the situation for not complying with the established rules $^{6}$.

Inconsistent Punishment is the second negative practice most often used by participants. The question that appeared for a large number of participants referred to educating the child according to the mother's mood state. When parents act, punishing, ignoring, or even applauding a behaviour according to their humour and not the child's behaviour, it confuses the child who learns to discriminate the mother's mood, and not if their behaviour was appropriate or inappropriate ${ }^{6}$. Thus, children tend to have more difficulty discriminating right and wrong ${ }^{18}$ and can learn to deal with difficult or stressful situations in the same way as parents, since they are models for them ${ }^{5}$. Parents need to be consistent in their own actions. When a mother experiences difficulties during the day and gets nervous at home, screaming and offering no attention to her child, independent of his or her behaviour, it becomes difficult to establish a stable emotional bond. The use of this practice can be a stressor for the child ${ }^{5}$.

The most reported questions from Negligence practice were related to the child staying a long time with other caregivers and not knowing what the child likes. The fact of being with others and caregivers can be justified because some mothers are still studying or working. This fact also influences mothers' knowledge about what her child likes, besides being influenced by the child's young age. Knowing what the infant likes or not, depends on the recognition of different expressions, vocalisations, facial expressions of the infant and the signals that he or she emits. These signals are important for mothers answering contingently and appropriately to infant's needs, for example, reassuring him or her and offering comfort when he or she shows fear. Therefore, we highlight the need to investigate the knowledge of mothers regarding infants' communication. 
Physical Abuse was not often reported by the mothers. Questions most frequently reported referred to hitting with hand or with objects. One study ${ }^{19}$ noted that the majority of child and adolescents families surveyed reported the use of corporal punishment. During the first year of life, very few mothers reported this practice. Therefore, this stage would be a great time to guide mothers and to prevent this practice in the future as children grow.

Most negative practices were not frequently reported in mothers' behavioural repertoire. Therefore, this stage would be a great moment to conduct preventive interventions, to install and strengthen the use of positive practices as well as to minimise and eliminate the use of negative practice. In this stage parenting practices and relationship patterns are still being established, and parental styles and practices may worsen as the child grows ${ }^{13}$. Positive Monitoring, which was frequency reported, could be used as a starting point for interventions with mothers of children in the first years of life.

\section{CONCLUSIONS}

This study aimed to describe and analyse the parenting educational practices of mothers in the first year of their child's life. The data showed that mothers tended to use positive practices with a high frequency, which are considered protective factors

\section{REFERENCES}

1. Sanders MR. Development, evaluation, and multinational dissemination of the triple PPositive Parenting Program. Annu Rev Clin Psychol. 2012; 8: 345-379. Doi: 10.1146/ annurev-clinpsy-032511-143104.

2. Mussen $\mathrm{PH}$, Conger JJ, Kagan J, Huston AC. Child Development \& Personality. New York: Harper \& Row; 1990.

3. Cecconello AM, De Antoni C, Koller SH. Socialization practices, parenting styles and physical abuse in familiar context. Psicologia em Estudo. 2003; 8: 45-54. Doi: 10.1590/ s1413-73722003000300007.

4. Cia F, Pamplin RCO, Del Prette ZAP. Communication and parent-children participation: a correlation with social skills and behavior problems of the children. Paidéia. 2006; 16 (35): 395-406. Doi: 10.1590/s0103$863 \times 2006000300010$.

5. Gomide PIC, Salvo CG, Pinheiro DPN, Sabbag G. M. A correlation between educative practices, depression, stress and social abilities. PsicoUSF 2005; 10 (2): 169-78. Doi: 10.1590/s141382712005000200008.

6. Gomide PIC. Inventários de Estilos Parentais (IEP): modelo teórico, manual deaplicação, apuração e interpretação. Rio de Janeiro: Editora Vozes; 2006.

7. Altafim ERP, Schiavo RA, Rodrigues OMPR. Parenting practices of adolescent mothers: an for child development. Even if negative practices also occurred, it is important to identify good practices and reinforce them to remain in the repertoire of mothers during child development. However, this draws attention to the presence of a negative practice Relaxed Discipline, which implies establishing rules, but not keeping them. This behaviour shows the child that there are rules, but they do not need to be met. This behaviour may have other consequences as the child grows and begins to attend larger environments with other significant adults or even with variety and more peers of their chronological age.

Another set of negative practices with high frequency was Inconsistent Punishment. When this practice is present, it teaches children to "read" the environment, but not to learn the meaning of the rule, since the mother tends to behave according to her mood in upholding or neglecting rule compliance.

The results of this study suggest that after the identification of mothers' parenting educational practices it is possible to implement specific interventional actions to enhance positive educational practices and reduce the negative practices, improving maternal educational practices and mother-child relationship. We emphasise the importance of educating mothers from the earliest years of life about their role in the interaction with their child and the use of appropriate parenting practices.

exploratory study. Temas sobre Desenvolvimento. 2008; 16: 104-110.

8. Dishion TJ, McMahon RJ. Parental monitoring and the prevention of child and adolescent problem behavior: a conceptual and empirical formulation. Clin Child Family Psychol Rev. 1998;1(1): 61-75. Doi: 10.1023/A:102180043 2380.

9. Gomide PIC. Pais presentes, pais ausentes: regras e limites. Petrópolis, RJ: Vozes; 2004.

10. Rodrigues OMPR, Altafim ERP, Schiavo RA, Valle TGM. Parenting style and parental practices of adolescents' mothers: an intervention program.Pediatr Moderna. 2011; 47(2): 5862.

11. Macarini SM, Martins GDF, Minetto, MFJ, Vieira, ML. Parental practices: a review of Brazilian literature. Arq Bras Psicol. 2010; 62(1): 119-34.

12. Minetto MF, Crepaldi MA, Bigras M, Moreira LC. Parental stress and educational practices of parents of young children with typical and atypical development. Educ Rev. Curitiba: 2012; (43):117-132. Doi: 10.1590/s010440602012000100009.

13. Rodrigues OMPR, Altafim ERP, Schiavo RA. Parental practices of adults and adolescents mothers with babies between one and twelve months. Aletheia. 2011; (34): 96-108.

14. Lopes RCS, Alfaya C, Machado CV, Piccinini CA. "In the beginning I used to leave with a broken heart": the first mother-infant separations. Rev 
Bras Crescimento Desenvolv Hum. 2005; 15(3): 26-35.10

15. Bolsoni-Silva AT, Paiva MM, Barbosa CG. Behavior problems in children/adolescents and difficulties for parents/caretakers: a characterization study. Psicologia Clínica. 2009; 21(1): 169-84. Doi: 10.1590/s0103-5665200 9000100012.

16. Moreira LVC,Biasoli-Alves ZMM. Educational practices: joint participation of mothers and their children in the determination of daily routine. Rev Bras Crescimento Desenvolv Hum. 2008; 18(1): 53-65.
17. Spradlin JE. Routines: implications for life and training. Temas Psicol. 1999; 7(3):223-34.

18. Carvalho MCN, Gomide PIC. Parental educational practices in families whose adolescents present law problems. Estud Psicol. Campinas: 2005;22(3): 263-75. DOI: 10.1590/ s0103-166x2005000300005.

19. Weber LND, Viezzer, AP, Brandenburg OJ. The use of spanking and physical punishment in parenting. Estud Psicol. Campinas: 2004; 9: 227-37. Doi: 10.1590/s1413-294×2004000 200004.

\section{Resumo}

As estratégias utilizadas pelos pais na educação e cuidados dos filhos possuem uma função primordial no desenvolvimento e saúde infantil. A presente pesquisa pretendeu descrever e analisar as práticas educativas maternas no primeiro ano de vida. Participaram da pesquisa 250 mães com filhos no primeiro ano de vida, de um a 12 meses de idade, nas quais foi aplicado o Inventário de Estilos Parentais para Mães de Bebês. Os resultados revelaram que as mães utilizam-se com frequência da prática parental positiva Monitoria Positiva, no entanto as práticas negativas, também são presentes no repertório das participantes, principalmente a prática Disciplina Relaxada. Como a maioria das práticas negativas ainda não são freqüentes no repertório comportamental das mães, esta fase seria portanto, um ótimo momento para a realização de intervenções preventivas que visem aprimorar o relacionamento mãe-criança, e consequentemente atuar na prevenção e promoção da saúde e do desenvolvimento.

Palavras-chave: práticas educativas, comportamento materno, relação mãe-criança, primeiro ano de vida, desenvolvimento infantil. 